\title{
PENGARUH PENYUNGKUPAN DAN PENGGUNAAN INSEKTISIDA TERHADAP POPULASI KUMBANG DAUN DAN KERUSAKAN PADA TANAMAN SAWI
}

\author{
Mirra Octavianty, Imas Vita Mulisa Murni \& F.X. Susilo \\ Bidang Proteksi Tanaman Jurusan Agroteknologi, Fakultas Pertanian, Universitas Lampung \\ Jl. Prof. Sumantri Brojonegoro No. 1 Bandar Lampung 35145 \\ E-mail: mirra.octavianty@yahoo.co.id
}

\begin{abstract}
Effect of plant caging and insecticide application on leaf beetle (Phyllotreta sp.) abundance and induced damage on mustard plants (Brassica rapa var. parachinensis L.). This study was aimed to test the efficacy of plant caging and insecticide treatment on the leaf beetle abundance and leaf beetle-induced damage on mustard plants. The field experiment consisted of three treatments (caging, insecticide and control) that were set in a completely randomized design with six replicates. Bamboo-framed screen cloth was used as cage while alfametrin was applied at recommended rate. The response variables were leaf beetle abundance (observed using a direct count method) and damage on mustard plants (percentage of severity and incidence). Result showed that plant caging effectively reduced pest abundance, damage severity (43\%) and damage incidence (83\%). Alfametrin spray slightly reduced leaf beetle abundance, damage severity (12\%) and damage incidence $(5 \%)$. Leaf beetle abundance positively correlated with damage severity $\left(\mathrm{R}^{2}=0.714\right)$. Addition of one leaf beetle individual increased damage severity of $5 \%$.
\end{abstract}

Key words: caging, alfametrin insecticide, Phyllotreta sp., mustard

\begin{abstract}
ABSTRAK
Pengaruh penyungkupan dan penggunaan insektisida terhadap populasi kumbang daun dan kerusakan pada tanaman sesawi. Penelitian ini bertujuan menguji efikasi penyungkupan tanaman versus insektisida kimia sebagai alternatif untuk mengendalikan hama kumbang daun pada tanaman sawi. Penelitian menggunakan rancangan acak lengkap dengan tiga perlakuan (penyungkupan, insektisida dan kontrol) dan enam ulangan. Sungkup dirakit dari kain tile yang diselubungkan pada kerangka bambu berukuran 2,5 m x $2 \mathrm{~m}$ x 1,5 m. Insektisida berbahan aktif alfametrin diaplikasikan dengan dosis, konsentrasi dan volume semprot anjuran. Kumbang daun diamati menggunakan metode penghitungan langsung sedangkan kerusakan tanaman dinyatakan dalam persen intensitas kerusakan dan persen tanaman rusak (terserang). Hasil penelitian menunjukkan bahwa penyungkupan tanaman dan penggunaan insektisida alfametrin dapat menekan kepadatan populasi kumbang daun dan kerusakan tanaman sawi. Penyungkupan dapat menekan populasi kumbang daun, baik ketika populasinya tinggi maupun ketika populasinya rendah. Penyungkupan dapat menekan intensitas kerusakan tanaman akibat serangan kumbang daun sebesar $43 \%$ dan menekan persentase tanaman terserang sebesar $83 \%$. Insektisida alfametrin juga dapat menekan populasi kumbang daun tetapi hanya ketika populasi hama itu rendah. Aplikasi alfametrin juga dapat menurunkan intensitas kerusakan tanaman dan persentase tanaman terserang, yaitu berturut-turut sebesar 12\% dan 5\%. Populasi kumbang daun berkorelasi positif dengan intensitas kerusakan pada tanaman sawi $\left(R^{2}=0,714\right)$. Setiap tambahan satu ekor kumbang daun di pertanaman sawi menaikkan intensitas kerusakan tanaman sebesar 5\%.
\end{abstract}

Kata kunci: penyungkupan, insektisida alfametrin, Phyllotreta sp., tanaman sesawi

\section{PENDAHULUAN}

Sawi hijau atau sawi merupakan salah satu komoditas sayuran yang digemari masyarakat. Daun tanaman sawi (Brassica rapa var. parachinensis, Capparales: Brassicaceae) dikonsumsi sebagai komponen menu kuliner favorit seperti mie bakso, mie ayam, dan berbagai macam masakan lainnya. Konsumen dapat mengakses produk ini di supermarketsupermarket, pasar induk, berbagai simpul lokasi transaksi sayuran dan pedagang sayuran keliling. Lahanlahan yang tidak terlalu luas dapat dimanfaatkan untuk membudidayakan tanaman ini. Untuk pertumbuhan dan perkembangan optimalnya tanaman yang genjah dan sukulen ini membutuhkan air dan sinar matahari yang memadai (Drost \& Johnson, 2010) oleh karena itu 
tidaklah mengherankan bila pertanaman sawi terkonsentrasi pada mosaik-mosaik lahan yang terbuka dan berkecukupan air.

Kendala utama dalam budidaya tanaman sawi adalah serangan hama, diantaranya ulat krop kubis (Crocidolomia binotalis Zeller, Lepidoptera: Pyralidae) dan kumbang daun atau kumbang anjing (Phyllotreta sp., Coleoptera: Chrysomelidae) (Kalshoven, 1981). Kedua jenis hama tersebut nampaknya dapat hidup berdampingan dengan berbagi relung pada tanaman sawi. Kerusakan yang mereka timbulkan pada tanaman dapat dikenali perbedaannya. Ulat krop kecil memakan bagian abaksial daun. Ulat yang lebih besar mengawali aktivitas makannya pada bagian tepi lembar daun kemudian melanjutkannya ke bagian-bagian lain di daun itu, menyisakan sebagian atau menghabiskannya sama sekali kemudian berpindah dan terus memakan lembarlembar daun berikutnya atau berhenti makan ketika tiba saatnya memupa. Kerusakan berat dicirikan oleh defoliasi yang masif, terutama pada daun-daun muda. Kumbang daun, di lain pihak, memakan daun sawi dengan cara melubangi daun-daun tersebut. Adanya lubang-lubang kecil itu (perforasi) berbentuk bundar, sedikit lonjong, bersudut atau gabungan dari bentukbentuk itu dengan ukuran milimeter pada daun merupakan gejala khas serangan hama ini. Tidak jarang, jumlah perforasi yang terjadi tidak cukup banyak; sebagai gantinya nampak banyak bintik kekuningan seukuran perforasi yang jelas merupakan bekas luka akibat gigitan kumbang itu pula, semacam gigitan yang dimulai dari bagian abaksial daun namun tidak dituntaskan sehingga tidak melubangi daun tersebut. Gejala ini, perforasi dan/atau bekas luka bintik kuning, memberikan kenampakan buruk pada daun sawi. Serangan berat mengakibatkan daun yang berlubanglubang atau berbintik kuning tersebut mengering; keseluruhan daun menjadi seperti terbakar tetapi mosaikmosaik bekas luka yang mengering itu masih mengesan sehingga secara keseluruhan kenampakan daun menjadi lebih buruk lagi. Pada kondisi tertentu, kerusakan akibat serangan kumbang daun dan akibat serangan ulat krop kubis dapat terjadi pada daun yang sama. Pola gejala gabungan yang terjadi memberikan indikasi sejauhmana interaksi kehidupan keduanya pada tanaman sawi. Serangan kedua jenis hama ini, baik secara mandiri maupun bersamaan, mengakibatkan terjadinya kerusakan kosmetis pada produk sayuran ini yang sulit ditolerir baik oleh produsen (petani) maupun konsumen .

Di lapangan, insektisida kimia masih lazim digunakan untuk mengendalikan hama-hama utama tanaman sawi, padahal cara itu tidak selalu efektif. Lagipula, insektisida yang disemprotkan biasanya meninggalkan residu yang tidak mudah hilang pada produk sayuran tersebut sehingga berbahaya bagi kesehatan konsumen. Studi Hasibuan et al. (2002) menunjukkan bahwa pada daun sawi ditemukan residu 12 bahan aktif dari tiga kelompok insektisida kimia, yaitu hidrokarbon berklor, organofosfat dan piretroid.

Sebetulnya penggunaan insektisida kimia bukanlah satu-satunya alternatif pengendalian hama tanaman sawi. Ada alternatif lain yang lebih rasional (Susilo, 2011), misalnya pengendalian secara mekanik dengan menyungkup tanaman. Pada pertanaman sawi, penyungkupan tanaman cukup efektif untuk menekan populasi ulat krop kubis serta menekan tingkat kerusakan yang diakibatkannya (Ferawati, 2009). Penyungkupan tanaman juga lebih ramah lingkungan. Namun belum diketahui apakah penyungkupan efektif untuk mengendalikan hama kumbang daun. Penelitian ini bertujuan menguji efikasi penyungkupan tanaman versus insektisida kimia sebagai alternatif untuk mengendalikan hama kumbang daun pada tanaman sawi.

\section{METODE PENELITIAN}

Tempat dan Waktu. Penelitian ini dilaksanakan di kawasan pertanaman sawi di Desa Way Kandis, Kecamatan Tanjung Senang Bandar Lampung, pada bulan Mei-Juni 2010. Kawasan ini berada $\pm 10 \mathrm{~km}$ dari pusat kota Bandar Lampung di arah timurlaut.

Rancangan Percobaan. Satuan percobaan berupa petak-petak pertanaman sawi berukuran $2 \mathrm{~m}$ x $1,5 \mathrm{~m}$ yang ditentukan secara acak dari bedengan-bedengan pertanaman sawi petani yang masing-masing berukuran $13,5 \mathrm{~m} \times 1,5 \mathrm{~m}$. Penanaman (pindahtanam) dengan jarak tanam $20 \mathrm{~cm} \times 20 \mathrm{~cm}$ dilakukan pada tanggal 3 Juni 2010. Seluruh satuan percobaan berjumlah 18 petak. Rancangan penelitian yang digunakan adalah rancangan acak lengkap dengan tiga perlakuan dan enam ulangan. Perlakuan yang dicobakan adalah penyungkupan, penyemprotan insektisida kimia dan kontrol. Ketiga perlakuan tersebut masing-masing dialokasikan secara acak pada 18 petak percobaan. Tanaman-tanaman sawi pada petak kontrol (enam petak) tidak disungkup dan tidak disemprot insektisida.

Penyungkupan. Sungkup yang digunakan adalah semacam kurungan, terdiri atas selubung kain tile berkerangka bambu. Kain tile berlubang saring $0,5 \mathrm{~mm}$ x $0,5 \mathrm{~mm}$ dirakitkan pada kerangka bambu sehingga menjadi kurungan atau sungkup berukuran (panjang $x$ lebar x tinggi) $2,5 \mathrm{~m} \times 2 \mathrm{~m} \times 1,5 \mathrm{~m}$. Penyungkupan tanaman dilakukan sejak hari tanam (segera setelah 
pindahtanam) sampai hari panen (tanggal 30 Juni 2010). Petak-petak yang disungkup (petak tersungkup, enam petak) tidak disemprot insektisida.

Aplikasi Insektisida. Insektisida berbahan aktif alfametrin ( $15 \mathrm{~g} /$ liter) diaplikasikan pada enam petak yang tidak disungkup (petak insektisida). Bahan formulasi insektisida disiapkan dengan konsentrasi $0,15 \%$ (v/v) dan disemprotkan dengan dosis $2 \mathrm{~L} /$ hektar. Penyemprotan dilakukan tiga kali, yaitu pada 17 hari setelah tanam (hst), 24 hst dan 31 hst. Alfametrin tidak termasuk salah satu dari 12 jenis insektisida yang residunya ditemukan di bahan tanaman sawi pada penelitian Hasibuan et al. (2002).

Pengamatan. Pengamatan dilakukan terhadap kepadatan populasi kumbang daun dan tingkat kerusakan yang diakibatkannya pada tanaman sawi. Kepadatan populasi didatakan dengan penghitungan langsung dari seluruh tanaman di dalam petak percobaan dengan bantuan hand-tally counter. Kemudian pada setiap petak percobaan ditentukan satu baris tanaman secara acak untuk penghitungan tingkat kerusakan. Tingkat kerusakan dinyatakan dengan dua variabel, yaitu intensitas kerusakan dan persentase tanaman rusak (terserang). Intensitas kerusakan (I) dihitung menggunakan rumus berikut :

$$
I_{i}=\frac{\sum n_{i} V_{i}}{Z N_{i}} \times 100
$$

dengan :

$\mathrm{I}_{\mathrm{i}}=$ intensitas kerusakan daun pada petak ulangan ke-i,

$\mathrm{n}_{\mathrm{i}}=$ jumlah tanaman berskor $\mathrm{V}_{\mathrm{i}}$ pada baris tanaman sampel pada petak ulangan ke- i,

$\mathrm{V}_{\mathrm{i}}=$ skor kerusakan setiap tanaman (0-4) pada baris tanaman sampel pada petak ulangan ke- $\mathrm{i}$ (Tabel 1),

$\mathrm{Z}=$ skor kerusakan tertinggi $(=4)$,

$\mathrm{N}_{\mathrm{i}}=$ jumlah seluruh tanaman sampel yang diamati pada petak ulangan ke-i,

$\mathrm{i}=$ ulangan $(1,2,3,4,5,6)$.
Nilai intensitas kerusakan ini menggambarkan seberapa parah atau berat kerusakan yang terjadi pada tanaman sawi yang terserang kumbang daun.

Adapun persentase tanaman rusak $(\mathrm{P})$ dihitung dengan rumus sederhana sebagai berikut :

$$
P_{i}=\frac{a_{i}}{b_{i}} \times 100
$$

dengan :

$P_{i}=$ persentase tanaman rusak atau terserang kumbang daun pada petak ulangan ke-i,

$a_{i}=$ banyaknya tanaman pada petak ulangan ke-i yang rusak atau terserang kumbang daun (daunnya mengalami perforasi / bermosaik kuning),

$b_{i}=$ banyaknya tanaman yang diamati pada petak ulangan ke-i,

$\mathrm{i}=$ ulangan $(1,2,3,4,5,6)$.

Nilai persentase tanaman rusak (terserang) menggambarkan berapa banyak tanaman sawi dari keseluruhan populasinya yang terserang oleh kumbang daun.

Analisis Data. Analisis data dilakukan pada taraf nyata 0,01 atau 0,05 . Data kepadatan populasi kumbang daun dan tingkat kerusakan tanaman dianalisis menggunakan uji $\mathrm{F}$ (ANOVA) pada taraf nyata 0,01 atau 0,05 dan dilanjutkan dengan uji Duncan pada taraf nyata 0,05 (Steel \& Torrie, 1995). Hubungan antara kepadatan populasi kumbang daun dan tingkat kerusakan tanaman dianalisis dengan uji korelasi dan regresi linier (Snedecor \& Cochran, 1980) pada taraf nyata 0,05 .

\section{HASIL DAN PEMBAHASAN}

Kepadatan Populasi Kumbang Daun. Hasil penelitian menunjukkan bahwa penyungkupan tanaman berpengaruh terhadap kepadatan populasi kumbang daun pada tanaman sawi (B. rapa var. parachinensis)

Tabel 1. Skor kerusakan pada daun sawi (V) akibat serangan kumbang daun

\section{Kriteria kerusakan}

Tidak ada kerusakan (tidak ada perforasi / mosaik kuning pada daun)

Kerusakan ringan (total perforasi / mosaik kuning pada daun $1-25 \%$ )

Kerusakan sedang (total perforasi / mosaik kuning pada daun $26-50 \%$ )

Kerusakan berat (total perforasi / mosaik kuning pada daun 51 - 75)

Kerusakan sangat berat (total perforasi / mosaik kuning pada daun $>75 \%$ )
Skor $(\mathrm{V})$

0


(Gambar 1). Pada 30 hst, 34 hst dan 37 hst populasi kumbang daun di petak tersungkup lebih rendah (nilai tengah $=2$ ekor $/$ tanaman) daripada di petak kontrol (nilai tengah $=7$ ekor $/$ tanaman). Dengan demikian penyungkupan secara signifikans dapat menekan populasi kumbang daun tetapi efek penekanan itu baru dapat terdeteksi setelah penyungkupan berlangsung selama minimal 30 hari (1 bulan).

Intensitas Kerusakan Tanaman. Penyungkupan juga berpengaruh terhadap intensitas kerusakan tanaman yang diakibatkan kumbang daun (Gambar 2). Pengaruh ini sudah terdeteksi sejak 20 hst. Dibandingkan dengan di petak kontrol, intensitas kerusakan tanaman di petak tersungkup lebih rendah. Pada petak-petak tersungkup tanaman mengalami kerusakan ringan, dengan nilai tengah $17 \%$ dan kisaran $9-23 \%$, sedangkan pada petak kontrol tanaman mengalami kerusakan berat, dengan nilai tengah 60\% dan kisaran $53-66 \%$. Dengan demikian dapat dinyatakan bahwa penyungkupan secara signifikans dapat menekan intensitas kerusakan tanaman, yaitu dari kategori rusak berat menjadi rusak ringan.

Penyungkupan mempengaruhi persentase tanaman rusak (Gambar 3). Persentase tanaman yang rusak akibat terserang kumbang daun di petak tersungkup lebih kecil (16\%) daripada di petak kontrol (99\%). Dengan kata lain, upaya penyungkupan dapat menyelamatkan sebanyak $83 \%$ tanaman sawi dari serangan kumbang daun. Efek penyelamatan yang kuat ini sudah nampak sejak 20 hst.

Insektisida alfametrin dapat menekan populasi kumbang daun namun pola dan tingkat penekanannya berbeda dengan penyungkupan. Perlakuan penyungkupan secara konsisten mampu menekan populasi kumbang daun sejak 30 hst (Gambar 1) dan menekan kerusakan pada tanaman sawi sejak 20 hst (Gambar 2,3) dengan tingkat penekanan yang signifikans baik dari aspek statistika maupun aspek teknis perlindungan tanaman. Tidak demikian halnya dengan efek insektisida alfametrin. Insektisida yang diaplikasikan sebanyak tiga kali itu pada saat-saat tertentu memang mampu menekan populasi kumbang daun (27 hst, 37 hst, Gambar 1) tetapi di saat-saat lain efek menekan itu tidak nampak (20 hst, 23 hst, 30 hst, 34 hst, Gambar 1). Informasi itu mengindikasikan bahwa insektisida ini mampu mengendalikan kumbang daun ketika populasinya rendah.

Demikian pula, insektisida alfametrin mampu menekan kerusakan tanaman yang diakibatkan oleh kumbang daun, tetapi nampaknya kemampuan itu tidak mantap. Pada 20 hst dan 37 hst insektisida alfametrin

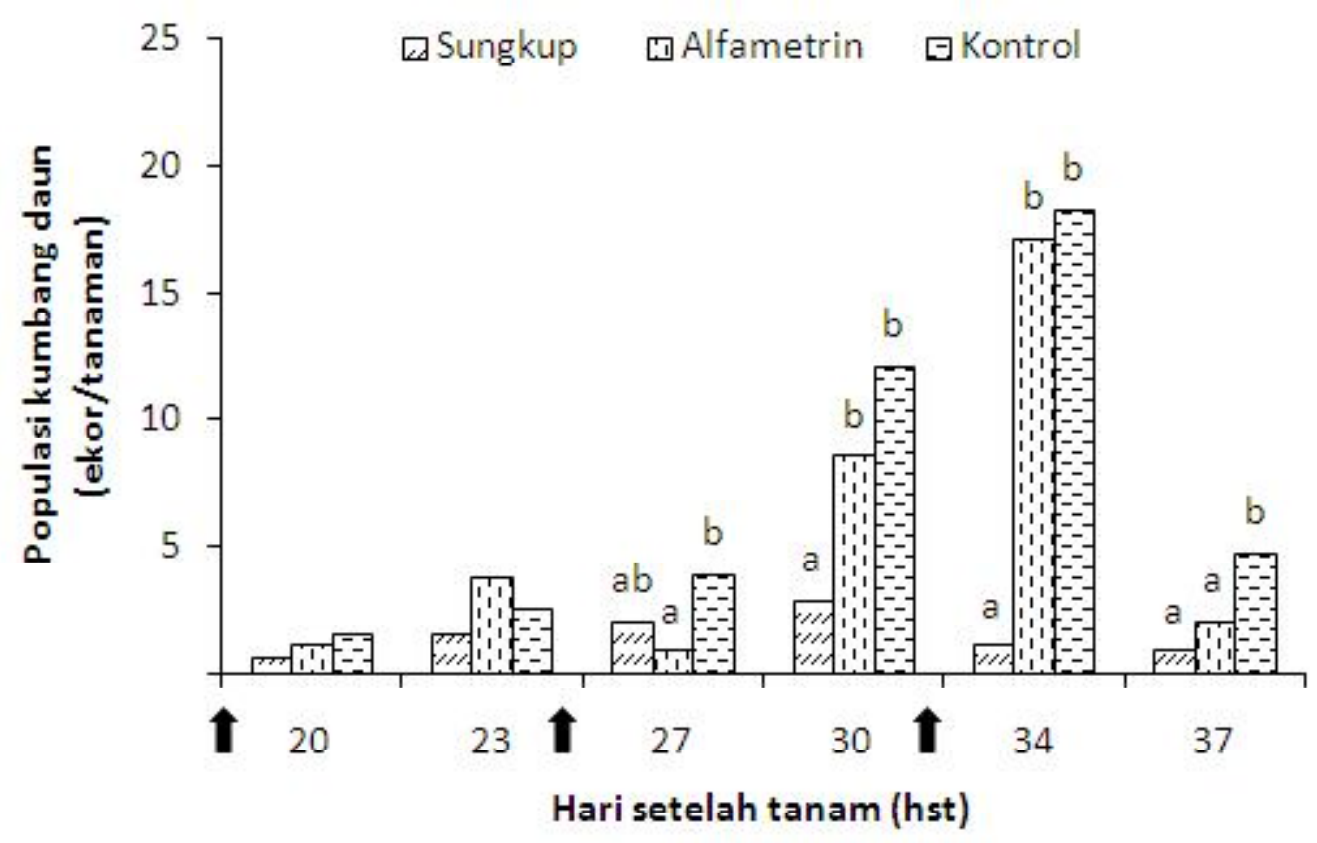

Gambar 1. Nilai tengah kepadatan populasi kumbang daun pada tanaman sawi yang diperlakukan dengan penyungkupan, insektisida kimia (alfametrin) dan kontrol. Notasi huruf yang sama pada hari-hari pengamatan menandakan nilai tengah tidak berbeda nyata menurut uji Duncan $(\mathrm{P}>0,05)$. Tanpa notasi huruf berarti uji $\mathrm{F}$ tidak nyata $(\mathrm{P}>0,05)$. Tanda panah menunjukkan waktu aplikasi insektisida alfametrin (17 hst, $24 \mathrm{hst}, 31 \mathrm{hst})$. 


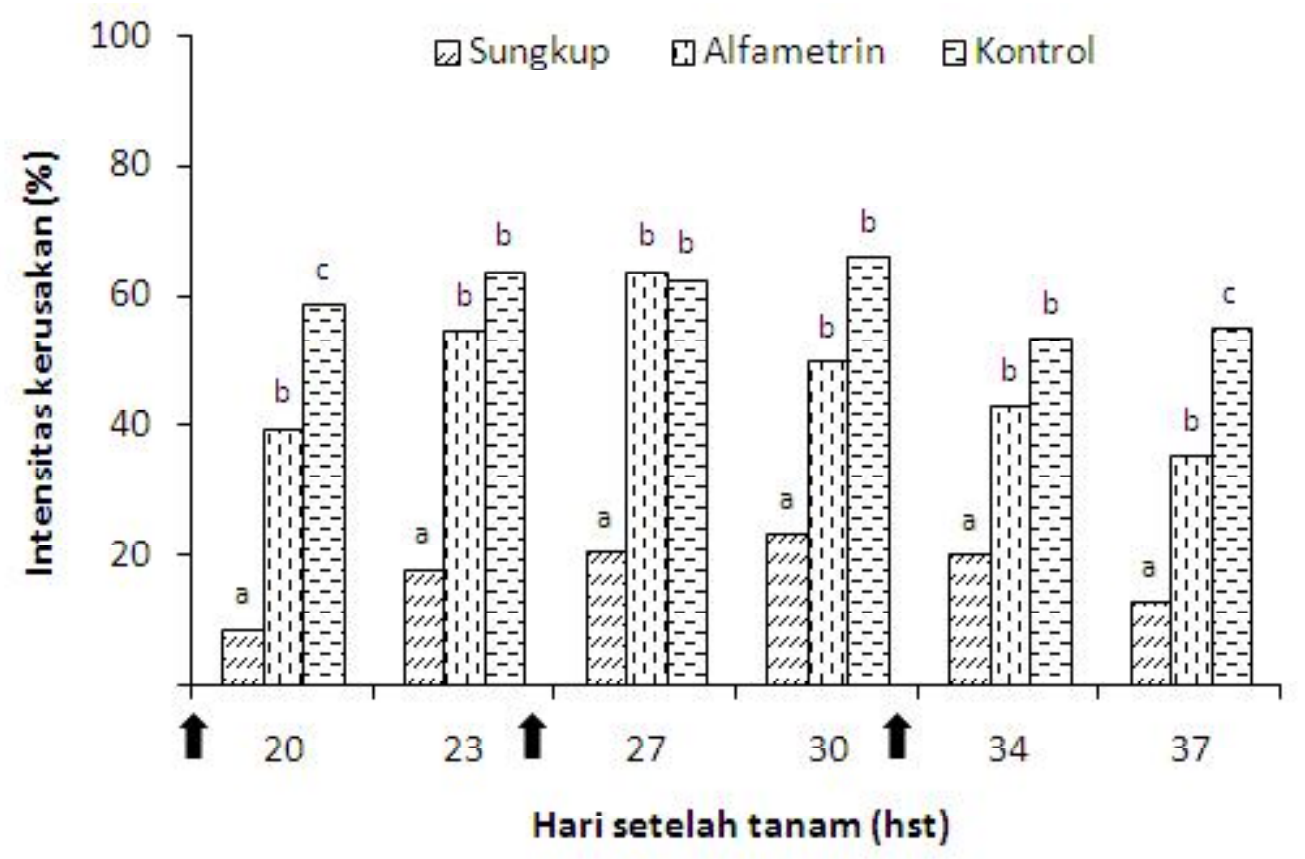

Gambar 2. Nilai tengah intensitas kerusakan akibat serangan kumbang daun pada tanaman sawi yang diperlakukan dengan penyungkupan, insektisida kimia (alfametrin) dan kontrol. Notasi huruf yang sama pada harihari pengamatan menandakan nilai tengah tidak berbeda nyata menurut uji Duncan $(\mathrm{P}>0,05)$. Tanpa notasi huruf berarti uji $\mathrm{F}$ tidak nyata $(\mathrm{P}>0,05)$. Uji-uji dilakukan terhadap data tertransformasi arcsinus. Tanda panah menunjukkan waktu aplikasi insektisida alfametrin (17 hst, 24 hst, 31 hst).

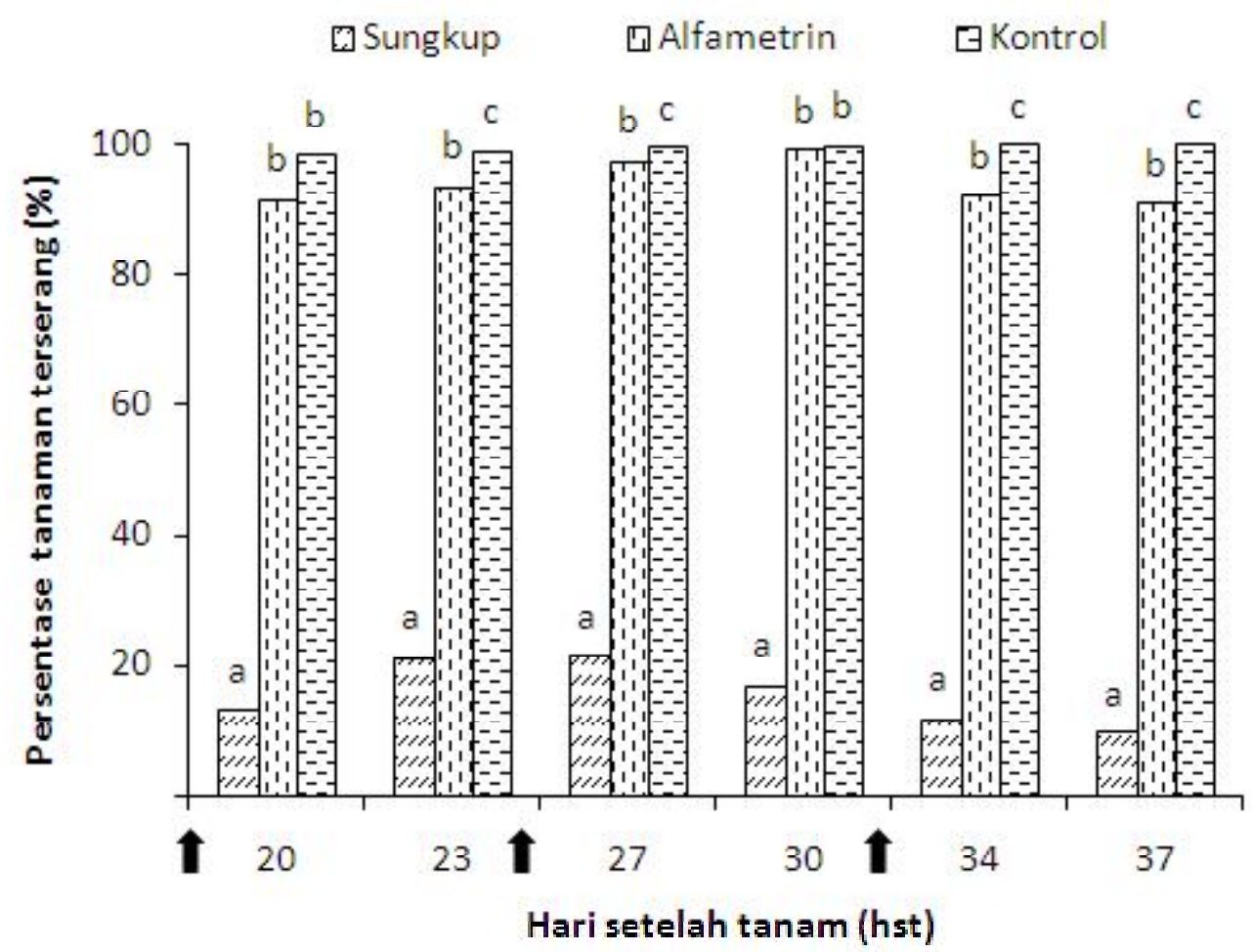

Gambar 3. Nilai tengah persentase tanaman terserang oleh kumbang daun pada petak yang diperlakukan dengan penyungkupan, insektisida kimia (alfametrin) dan kontrol. Notasi huruf yang sama pada hari-hari pengamatan menandakan nilai tengah tidak berbeda nyata menurut uji Duncan $(P>0,05)$. Tanpa notasi huruf berarti uji $\mathrm{F}$ tidak nyata $(\mathrm{P}>0,05)$. Uji-uji dilakukan terhadap data tertransformasi arc-sinus. Tanda panah menunjukkan waktu aplikasi insektisida alfametrin (17 hst, 24 hst, 31 hst). 
mampu menekan intensitas kerusakan sedangkan pada 23 hst, 27 hst, 30 hst dan 34 hst tidak mampu (Gambar 2). Aplikasi insektisida ini pun pada situasi-situasi tertentu (23 hst, 27 hst, 34 hst dan 37 hst) mampu menekan persentase tanaman rusak sedangkan pada situasi lain (20 hst dan 30 hst) tidak mampu (Gambar 3). Ketika insektisida itu mampu menekan kerusakan tanaman, maka tingkat penekanannnya lebih kecil dibandingkan dengan tingkat penekanan oleh penyungkupan, yaitu dengan nilai tengah $12 \%$ (alfametrin) versus $43 \%$ (penyungkupan) untuk penekanan intensitas kerusakan dan 5\% (alfametrin) versus 83\% (penyungkupan) untuk penekanan persentase tanaman rusak.

Alfametrin atau alfa-sipermetrin boleh jadi bukanlah insektisida yang paling efektif untuk mengendalikan kumbang daun pada tanaman sawi dan sawian lainnya. Meskipun demikian, persistensi insektisida ini rendah. Tidak ditemukannya residu alfametrin pada bahan tanaman sawi (Hasibuan et al., 2002) kiranya dapat mengindikasikan hal itu. Selain itu, Kumar et al. (2000) melaporkan bahwa pada 28 hari setelah penyemprotan memang masih ada residu alfametrin tertinggal di daun tanaman sawian $B$. campestris tetapi konsentrasinya di bawah batas maksimum residu (BMR) yang diizinkan. Residu alfametrin tidak mereka temukan pada sampel biji tanaman dan tanah yang diperiksa setelah panen.

Dinamika populasi kumbang daun memiliki pola umum yang mirip dengan dinamika kerusakan pada tanaman yang diakibatnya, yaitu rendah pada awal musim tanam kemudian naik dan akhirnya merendah lagi menuju penghujung musim tanam. Namun yang paling mirip adalah dinamika keduanya pada perlakuan penyungkupan (Gambar 1, 2, 3). Hasil analisis korelasi mengonfirmasi hal itu secara lebih tajam dan spesifik, yaitu bahwa kepadatan populasi kumbang daun berkorelasi positif dengan intensitas kerusakan tanaman, dan itu hanya terjadi pada petak tersungkup (Tabel 2). Pada petak-petak ini naiknya intensitas kerusakan sejalan dengan meningkatnya kepadatan populasi kumbang daun; demikian pula, turunnya intensitas kerusakan sejalan dengan berkurangnya kepadatan populasi kumbang daun. Adanya korelasi antara populasi kumbang daun dan kerusakan tanaman sawian lainnya (kanola, B. rapa) juga dilaporkan oleh Andersen et al. (2006). Mereka melaporkan bahwa populasi dua spesies kumbang daun ( $P$. cruciferae dan $P$. striolata) berkorelasi positif dengan jumlah luka / perforasi yang diakibatkan pada daun kanola.

Terjadinya penurunan intensitas kerusakan tanaman menuntun kepada dugaan bahwa tanaman sawi yang terserang memiliki sedikit kemampuan untuk bertahan terhadap serangan kumbang daun ketika situasi memungkinkan. Traw \& Dawson (2002) dan Soroka et al. (2011) menunjukkan bahwa tanaman dari golongan sawian atau sesawi (Brassicaceae) memang mampu menahan serangan kumbang daun dengan memroduksi lebih banyak trikhoma (rambut daun) yang tidak disukai oleh hama tersebut. Mekanisme ketahanan lainnya adalah melalui toleransi tanaman. Bodnaryk \& Lamb (1991) melaporkan terjadinya fenomena toleransi ini pada tanaman sawian yang lain lagi, yaitu Sinapis alba. Bibit tanaman $S$. alba yang diperlakukan dengan kumbang daun $P$. cruciferae menunjukkan pertumbuhan normal, yaitu tumbuh sebaik bibit yang tidak mengalami kerusakan (diperlakukan tanpa $P$. cruciferae) sementara bibit tanaman kanola $B$. napus (non-toleran) yang diperlakukan dengan $P$. cruciferae menunjukkan pertumbuhan yang buruk. Tanaman sawi (dalam penelitian ini) nampaknya juga memiliki sedikit daya tahan terhadap serangan kumbang daun, dan bila betul demikian maka ketahanan itu tidak terekspresi melalui rambut daun (morfologis) melainkan melalui kompensasi pertumbuhan (toleransi). Walaupun tidak mampu mengatasi infestasi hama secara mencolok, tanaman sawi nampaknya mampu mengompensasi sebagian jaringan-jaringannya yang terluka ketika infestasi hama mengendur sebagai konsekuensi dari antiklimaks populasi hama menjelang akhir musim tanam. Itu pun kemungkinan besar hanya terjadi pada tanamantanaman sawi di dalam sungkup.

Sejumlah kumbang daun memang ada yang berhasil menembus sungkup tetapi sebagian besar dari mereka tereksklusi secara mekanis oleh dinding sungkup.

Tabel 2. Korelasi linier (r) antara kepadatan populasi kumbang daun dan dua variabel kerusakan pada tanaman sawi pada perlakuan penyungkupan, insektisida kimia (alfametrin) dan kontrol

\begin{tabular}{lccc}
\hline Variabel kerusakan tanaman & Sungkup & Alfametrin & Kontrol \\
\hline Intensitas kerusakan & $0,845^{*}$ & $-0,170^{\text {ns }}$ & $-0,312^{\text {ns }}$ \\
Persentase tanaman rusak & $0,605^{\text {ns }}$ & $0,009^{\text {ns }}$ & $0,662^{\text {ns }}$ \\
\hline
\end{tabular}

Komputasi dilakukan terhadap sampel yang digabung pada hari pengamatan yang sama $(n=6)$. Koefisien korelasi tidak berbeda dengan nol (ns; $\mathrm{P}>0,05)$ atau berbeda dengan nol $(*, \mathrm{P}<0,05)$. 


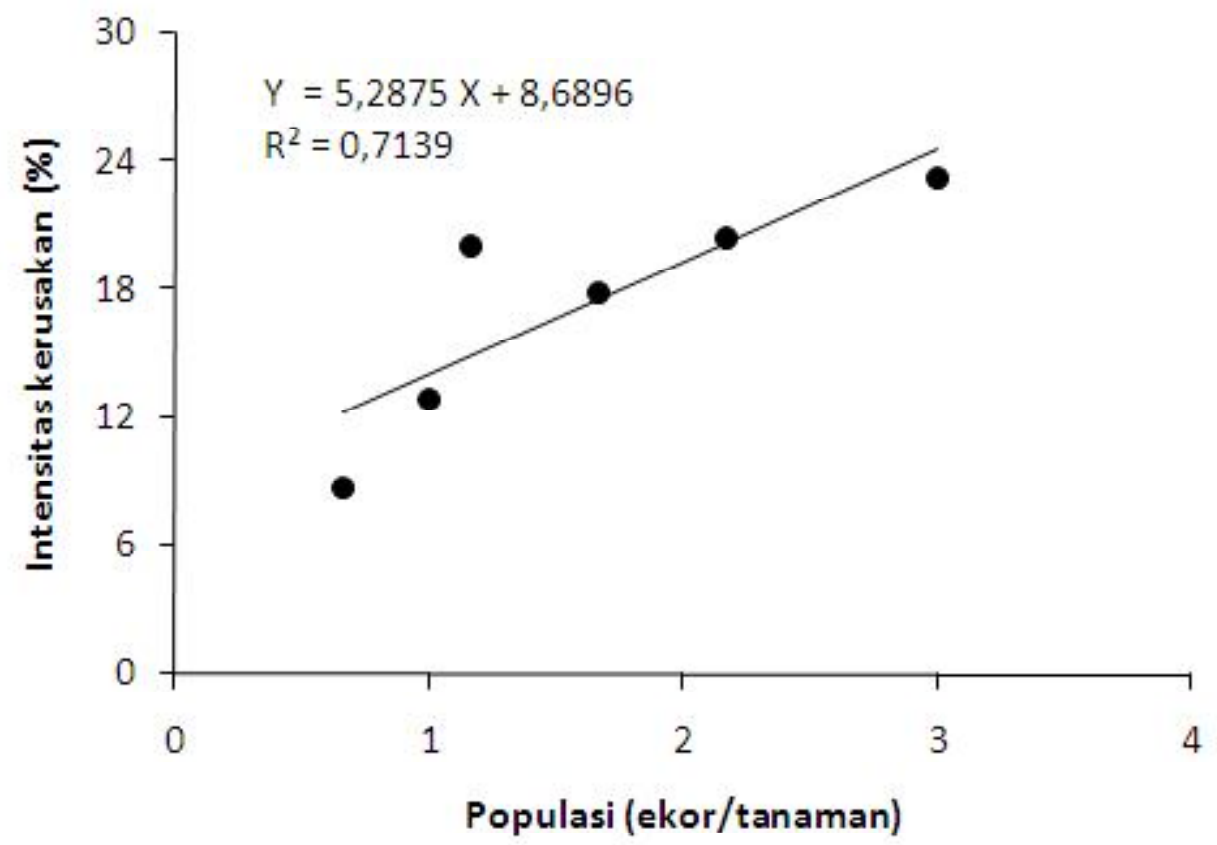

Gambar 4. Hubungan antara kepadatan populasi kumbang daun dan intensitas kerusakan tanaman sawi pada petak tersungkup. Signifikansi ditentukan melalui Uji $\mathrm{t}(\mathrm{P}<0,05)$

Populasi sejumlah kumbang daun di dalam sungkup inilah yang rupanya berdinamika dan berinteraksi dengan tanaman di dalam sungkup hingga korelasinya terdeteksi positif (Tabel 2; Gambar 4). Gambar 4 mengilustrasikan bahwa semakin tinggi populasi kumbang daun yang berada di tanaman sawi semakin berat intensitas kerusakan tanaman yang terjadi. Setiap penambahan seekor kumbang daun pada tanaman meningkatkan intensitas kerusakan sebesar 5\%.

Tanaman sawi di luar sungkup nampaknya tidak memiliki kesempatan untuk menyembuhkan diri dari luka akibat serangan kumbang daun karena tingginya populasi kumbang daun di situ. Sebagai gambaran, pada 34 hst populasi kumbang daun di dalam sungkup sudah mulai menurun (dari 3 ekor / tanaman menjadi 1 ekor / tanaman) tetapi di luar sungkup justru masih meningkat, yaitu dari 9 ekor / tanaman menjadi 17 ekor / tanaman (pada petak insektisida) dan dari 12 ekor / tanaman menjadi 18 ekor / tanaman (pada petak kontrol). Bahkan, tingkat populasi kumbang daun yang aktif di petak kontrol pada hari itu kemungkinan lebih tinggi lagi. Populasi yang terdata adalah hasil pengamatan dari pukul 06.00 sampai pukul 10.00 waktu Indonesia Bagian Barat. Murni (2011) dapat menunjukkan bahwa semakin siang kepadatan populasi kumbang daun semakin tinggi hingga mencapai dua kali lipat menjelang pukul 14.00. Kepadatan populasi kumbang daun yang demikian tinggi itu mengindikasikan infestasi masif yang tidak tertahankan oleh tanaman sawi di luar sungkup.

\section{SIMPULAN}

Hasil penelitian menunjukkan bahwa penyungkupan tanaman dan penggunaan insektisida alfametrin berpengaruh terhadap kepadatan populasi kumbang daun dan kerusakan pada tanaman sawi. Penyungkupan dapat menekan populasi kumbang daun, baik ketika populasi hama itu tinggi (dari 18 ekor / tanaman menjadi 1 ekor / tanaman) maupun ketika populasi hama rendah (dari 5 ekor / tanaman menjadi 1 ekor / tanaman). Penyungkupan dapat menekan intensitas kerusakan tanaman akibat serangan kumbang daun (dari 60\% menjadi 17\%) dan menekan persentase tanaman terserang kumbang daun (dari 99\% menjadi $16 \%$ ). Insektisida alfametrin juga mampu menekan populasi kumbang daun tetapi penekanan itu terjadi ketika populasi hama rendah (dari 4 - 5 ekor / tanaman menjadi 2 ekor / tanaman). Aplikasi insektisida itu juga mampu menurunkan intensitas kerusakan tanaman dan persentase tanaman rusak tetapi tingkat penekanan yang diperoleh lebih rendah daripada tingkat penekanan oleh penyungkupan, yaitu berturut-turut dari $60 \%$ menjadi $48 \%$ (intensitas kerusakan tanaman) dan dari $99 \%$ menjadi 94\% (persentase tanaman terserang). Populasi 
kumbang daun mempengaruhi intensitas kerusakan pada tanaman sawi $\left(\mathrm{R}^{2}=0,714\right)$. Setiap tambahan satu ekor kumbang daun di pertanaman sawi menaikkan intensitas kerusakan tanaman sebesar 5\%.

\section{SANWACANA}

Ucapan terima kasih disampaikan kepada Bapak Burhan atas keikhlasan meminjamkan lahan pertanaman sawinya untuk digunakan dalam penelitian ini. Penulis juga mengapresiasi bantuan teknis dan non-teknis dari Novitasari Darwin.

\section{DAFTAR PUSTAKA}

Andersen CL, Hazzard R, Van driesche R \& Mangan FX. 2006. Alternative management tactics for control of Phyllotreta cruciferae and Phyllotreta striolata (Coleoptera: Chrysomelidae) on Brassica rapa in Massachusetts. (Abstract, references, figures, tables \& citations). J.Econ. Entomology 99(3):803 - 810.

Bodnaryk RP \& Lamb RJ. 1991. Mechanisms of resistance to the flea beetle, Phyllotreta cruciferae (Goeze), in mustard seedlings, Sinapis alba L. (Abstract \& citations). Canadian Journal of Plant Science 71(1): 13 - 20.

Drost D \& Johnson M. 2010. Mustard in the garden. Utah State University Cooperative Extension Work. HG/Garden/2005-07pr.

Ferawati A. 2009. Uji penyungkupan untuk mengendalikan hama utama tanaman sawi (Brassica juncea L.). Skripsi. Fakultas Pertanian Universitas Lampung, Bandar Lampung.

Hasibuan R, Akin HM \& Swibawa IG. 2002. Studi pencemaran residu pestisida dan $\mathrm{k}$ a it a n ny a dengan kegiatan proteksi tanaman sayuran di Kota Bandar Lampung. Laporan Pendahuluan. Kerjasama antara Pemerintah Kota Bandar Lampung dan Lembaga Penelitian Universitas Lampung, Bandar Lampung.
Kalshoven LGE. 1981. The Pests of Crops in Indonesia. van der Laan PA (Rev. \& trans.) Rotschild GHL (Asssist.) PT Ichtiar Baru - van Hoeve, Jakarta.

Kumar R, Dikshit AK \& Prasad SK. 2000. Persistence and safety evaluation of alphamethrin on mustard (Brassica campestris Linn.) (Abstract). Bulletin of Environmental Contamination and Toxicology 65 (2): 200 - 206.

Murni IVM. 2011. Dinamika populasi kumbang daun (Chrysomelidae) pada tanaman sawi (Brassica juncea L.) dalam kurun waktu 24 jam. Skripsi. Fakultas Pertanian Universitas Lampung, Bandar Lampung.

Snedecor GW \& Cochran WG. 1980. Statistical Methods. Iowa State University Press, Ames.

Soroka JJ, Holowachuk JM, Gruber MY \& Grenkow LF. 2011. Feeding by flea beetles (Coleoptera: Chrysomelidae; Phyllotreta spp.) is decreased on canola (Brassica napus) seedlings with increased trichome density. (Abstract \& references). J. Econ.Entomology 104(1):125136.

Steel RGD \& Torrie JH. 1995. Prinsip dan Prosedur Statistika. Terj. Bambang Sumantri. Gramedia Pustaka, Jakarta.

Susilo FX. 2011. Serangga di Ekosistem Pertanian: Keanekaragaman, Interelasi dan Prospek Pengelolaannya Secara Bio-rasional. Orasi Ilmiah dalam Rangka Pengukuhan Guru Besar Tetap Bidang Entomologi Pertanian Fakultas Pertanian Universitas Lampung, 23 Pebruari 2011, Bandar Lampung.

Traw MB \& Dawson TE. 2002. Reduced performance of two specialist herbivores (Lepidoptera: Pieridae, Coleoptera: Chrysomelidae) on new leaves of damaged black mustard plants. Environmental Entomology 31(4): 714 - 722. 